\title{
EXPLORATORY AND EXPLOITATIVE MARKET LEARNING IN DISCONTINUOUS NEW PRODUCT DEVELOPMENT
}

\author{
Armand Smits \\ Geert Vissers \\ Jan de Wit
}

\begin{abstract}
Institute for Science, Innovation and Society, Radboud University, PO Box 9010, 6500 GL, Nijmegen, The Netherlands

armand.smits@science.ru.nl; g.vissers@science.ru.nl; j.dewit@ science.ru.nl
\end{abstract}

\section{SUMMARY}

This research presents the results of an inductive comparative case study of how exploratory and exploitative market learning is balanced during the development of eight discontinuous new product development projects in six different business units of different multinationals in the chemical industry. For these projects, all recently introduced into the market, we find market knowledge to be a multi-dimensional construct consisting of segment, product, application, and customer knowledge. We illustrate how a project's exploratory and exploitative market learning is balanced across market knowledge dimensions and over time. More specifically, we find three generic market learning patterns that can be distinguished based on their trade-off between exploratory and exploitative market learning. Our data also allow us to identify several organizational arrangements, such as the organizational position of the projects' core marketing function and senior management's decision roles, which seem important in shaping different market learning patterns. Overall this research contributes to the emerging literature on exploratory market learning in new product development.

\section{INTRODUCTION}

New product development (NPD) allows organizations to cope with changing environments and renew themselves (Danneels, 2002). To develop new products, the significance of a market viewpoint has been recognized throughout the NPD and marketing literature (see e.g. Atuahene-Gima, 1995; Cooper, 2001; Li and Calantone, 1998; Moorman, 1995). This viewpoint is captured by the concept of 'market orientation' (Kohli and Jaworski, 1990; Narver and Slater, 1990). According to a recent meta-analysis, a market orientation positively impacts new product market acceptance and organizational performance (Kirca et al., 2005). Following this approach, organizations should generate, disseminate and use market knowledge while innovating. Other research that adopts a market learning approach, which shares many elements with market orientation's behavioral perspective (Bell et al., 2002), has pointed into the same direction (Adams et al., 1998; Moorman, 1995).

While there is much support for the benefits of a market orientation and market learning in NPD, the concepts have also been criticized. Most of this critique relates to overemphasizing the importance of current customers and their expressed wants and needs, as well as current market structures. Critics have warned for the dark side of customer intimacy and have argued that it will lead to too much continuous and trivial product development (Bennet and Cooper, 1981), myopic R\&D initiatives (Frosch, 1996), and loss of industry leadership (Christensen and Bower, 1996). Marketing scholars have responded to this criticism by emphasizing that market orientation and market learning are not limited to current customer needs and wants, and current market structures. This has resulted in a refining of the constructs into dichotomies such as market-driven vs. market driving orientations (Jaworski et al., 2000), a reactive vs. a proactive market orientation (Narver et al., 2004), adaptive vs. generative market learning (Slater and Narver, 1998), and exploitative vs. exploratory market 
learning (Atuahene-Gima et al., 2005). While the former part of these dichotomies refers to the type of market orientation, or market learning, that is beneficial for the refinement of current products for current markets (continuous NPD), the latter part is helpful in situations of product development that moves the organization into new fields, and deviates from current organizational knowledge resources (discontinuous NPD). Additionally, it has been established that there are differences between continuous NPD and discontinuous NPD in the nature and timing of the market-related enquiry (Song and Montoya-Weiss, 1998) and the appropriate market knowledge generating techniques (Leonard-Barton, 1995; Urban and Von Hippel, 1988)

Although this work has been highly beneficial for understanding market oriented NPD, it ignores the argument, stemming from outside the marketing and NPD fields, that for discontinuous innovation, exploratory market learning is only half the story (see e.g. Cheng and Van de Ven, 1996; Duncan, 1976; McGrath, 2001). While continuous NPD may rely on exploitative learning (refinement of the firm's existing knowledge resources), discontinuous NPD needs both exploration and exploitation. On the one hand exploratory learning is beneficial for variance creation and discovery, on the other hand exploitative learning is necessary to fix and develop the new knowledge, so that eventually the discontinuous NPD team can capitalize on its discoveries. Thus, while exploration is necessary for project phases of divergence, exploitative learning is necessary when the project has to run into convergence (March, 1991). Although this seems obvious in theory, it appears to be much harder to realize in practice. To balance these conflicting types of learning, referred to as the "central paradox of administration' (Thompson, 1967), firms need complicated organizational designs (Raisch and Birkinshaw, 2008).

While there is a small but growing body of marketing and NPD literature on the importance of balancing exploration and exploitation in market learning for portfolios of different NPD projects at the organizational level (Atuahene-Gima et al., 2005; Morgan and Berthon, 2008; Tsai et al., 2008), there is less literature on how this balance is achieved in single discontinuous NPD projects. Additionally, there is only limited work on how firms' marketing organizations deal with the tension between exploratory and exploitative market learning in single discontinuous NPD projects. In the remainder of this article we address these issues by presenting the findings of an inductive comparative case study of how exploratory and exploitative market learning is balanced in individual discontinuous NPD projects. Additionally, we specify the overarching structures and systems of the project's context that facilitated the observed market learning behavior. For our research we adopt the perspective of learning as generating market knowledge and integrating it during NPD activities (De Luca and Atuahene-Gima, 2007; Grant, 1996). Additionally, we follow Gupta et al. (2006) who argue that all activity includes at least some learning. Even when NPD project members do nothing more than replicating past actions, they accumulate experiences and move down the learning curve, albeit in an incremental manner. So, rather then focusing on the presence or absence of learning, we focus on the type of learning.

With our study we illustrate that market knowledge is a multidimensional construct, and that exploration and exploitation in a project's market learning are balanced across market knowledge dimensions and over time. Based on different trade-offs in exploratory and exploitative market learning we are able to identify several market learning patterns. These patterns seem to require their own specific marketing organization arrangements for balancing exploration and exploitation. 


\section{RESEARCH DESIGN}

This research utilizes an inductive comparative case study. This strategy is appropriate for enriching or extending theories through an iterative process, and answering 'how' and 'why' questions (Eisenhardt, 1989; Yin, 1994). It allows for an investigation of how market learning in discontinuous NPD projects unfolds in a real world environment and why decisions actually take place. Additionally, a comparative case study enables a replication logic in which the set of cases is treated as series of experiments, with each case serving to confirm or disconfirm the inferences drawn from the others (Yin, 1994). A multiple case study typically results in better grounded and more general theory than single cases. The theoretical and the empirical inquiries are not addressed sequentially, but via an interactive process that exists between existing theories and data where incongruities are solved in a subsequent iteration (Eisenhardt, 1989). The strategy also allows for the incorporation of a variety of different sources of evidence, including archival documents and interviews.

The investigation has focused on discontinuous NPD projects. At the project level, actual change in the content of the organizational knowledge resources takes place and attempts are made to balance exploratory and exploitative market learning. Given the importance of the firms' organizational arrangement, we also include the context of these market learning patterns, as being the overarching structures and systems of a business unit which is external to these learning patterns but facilitates or inhibits them.

Qualitative sampling, unlike quantitative sampling, tends to be purposive, rather than random. The choices of informants, episodes, and interactions are usually driven by a conceptual question. In this particular case, we gathered data on eight discontinuous NPD projects that were part of six mature business units of different multinationals (see table 1). Although the projects are part of different product categories, all business units are active in the chemical industry. Limiting the empirical context of our study to one specific industry eliminates cross-industry differences that can impact the organization of marketing activities or the manifestation of market knowledge and allows us to better focus on differences and common themes across projects (King and Zeithaml, 2003). Upfront we intended to include a variety of different discontinuous NPD projects. Together with an informant who had a good overview of the business units' innovation projects, such as a business manager, a marketing manager or an R\&D manager, we selected one or two projects for further study. To qualify as a discontinuous NPD project, a project had to be aimed at the development of a new product and/or extending the customer base of the business unit (Johne, 1994). At the start of the study, the outputs of all new product initiatives were recently introduced into the market and generated spin-off projects, or were close to market introduction.

Because discontinuous NPD in the context of mature organizations can be difficult (Dougherty and Hardy, 1996), financial success can take many years after market introduction (Sorescu et al., 2003), and many new product ideas and concepts eventually fail to be launched into the market (Cooper, 2001), we consider the launch of a discontinuous NPD initiative as an intermediate measure for project success.

Data collection involved two waves. After negotiating access to the business unit we first aimed at getting familiar with the, often complex, organizational characteristics. We held 2 to 8 interviews on different hierarchical levels to get familiar with the business units' products, innovation strategy and processes, and marketing and R\&D organization. These interviews were not specifically discussing projects, were semi-structured around the themes mentioned above, and lasted from 1.5 to 2.5 hours. We recorded the interviews and transcribed them verbatim. We complemented these interviews with internal archival data on the business units, such as annual reports, presentations, newsletters, and press releases, and external 
Table 1: Description of the cases and the case data

\begin{tabular}{|c|c|c|c|c|}
\hline $\begin{array}{l}\text { Project } \\
\text { Pseudonym }\end{array}$ & $\begin{array}{l}\text { Project } \\
\text { Description }\end{array}$ & $\begin{array}{l}\text { Project data sources } \\
\text { \# interviews } \\
\text { \# pages archival } \\
\text { data }\end{array}$ & $\begin{array}{l}\text { Organizational home } \\
\text { (business unit turnover } \\
\text { in billion } € \text { ) }\end{array}$ & $\begin{array}{l}\text { Organizational home } \\
\text { data sources } \\
\text { \# interviews } \\
\text { \# pages archival data }\end{array}$ \\
\hline (1) High Heat & $\begin{array}{l}\text { New engineering } \\
\text { plastic grade for } \\
\text { automotive 'under } \\
\text { the hood' market }\end{array}$ & $\begin{array}{c}3 \\
30\end{array}$ & \multirow{2}{*}{$\begin{array}{ll} & \text { BU turnover: } 0.8 \\
\text { - } & 5 \text { Product lines, } \\
& \text { including research } \\
\text { - } & \text { Separate sales } \\
& \text { organization }\end{array}$} & \multirow[t]{2}{*}{$\begin{array}{c}6 \\
290\end{array}$} \\
\hline (2) Bond & $\begin{array}{l}\text { Using existing } \\
\text { engineering plastic } \\
\text { to replace metal } \\
\text { backbones in } \\
\text { metal/ rubber } \\
\text { components market }\end{array}$ & $\begin{array}{c}3 \\
30\end{array}$ & & \\
\hline (3) Foam & $\begin{array}{l}\text { New high } \\
\text { performance foam }\end{array}$ & $\begin{array}{c}3 \\
150 \\
\end{array}$ & \multirow{2}{*}{$\begin{array}{ll} & \text { BU turnover: } ~ \\
\text { - } & 7 \text { Product lines } \\
& \text { including research } \\
\text { - } & \text { Separate sales } \\
& \text { organization } \\
\text { - } & \text { Separate marketing } \\
& \text { organization }\end{array}$} & \multirow[t]{2}{*}{$\begin{array}{c}3 \\
300\end{array}$} \\
\hline (4) $D y e$ & $\begin{array}{l}\text { New functional } \\
\text { resin system for } \\
\text { anti-counterfeiting } \\
\text { market }\end{array}$ & $\begin{array}{l}3 \\
90\end{array}$ & & \\
\hline (5) Anti-resist & $\begin{array}{l}\text { New additive for } \\
\text { tire market }\end{array}$ & $\begin{array}{c}3 \\
20\end{array}$ & $\begin{array}{ll} & \text { BU turnover: } ~ 0.4 \\
\text { - } & \text { Single product firm } \\
\text { - } & 8 \text { Product/market } \\
& \text { sales groups } \\
\text { - } & \text { Separate research } \\
& \text { organization } \\
\end{array}$ & $\begin{array}{c}8 \\
80\end{array}$ \\
\hline (6) Diffuse & $\begin{array}{l}\text { Using existing } \\
\text { engineering plastic } \\
\text { for newly } \\
\text { developed license } \\
\text { plate system }\end{array}$ & $\begin{array}{c}2 \\
80\end{array}$ & $\begin{array}{ll} & \text { BU turnover: } 0.4 \\
\text { - } & 4 \text { Product lines } \\
\text { - } & \text { Separate research } \\
& \text { organization } \\
\text { - } & \text { Separate sales } \\
& \text { organization }\end{array}$ & $\begin{array}{c}2 \\
90\end{array}$ \\
\hline (7) Extend & $\begin{array}{l}\text { Using existing } \\
\text { functional polymer } \\
\text { in plastic additives } \\
\text { market }\end{array}$ & $\begin{array}{c}3 \\
150\end{array}$ & $\begin{array}{ll} & \text { BU turnover: 0.4 } \\
\text { - } 2 \text { Businesses with } \\
\text { own sales and } \\
\text { research }\end{array}$ & $\begin{array}{c}1 \\
290\end{array}$ \\
\hline (8) $\mathrm{Bio}$ & $\begin{array}{l}\text { New bio-based } \\
\text { chemical ingredient } \\
\text { for epoxy-resin } \\
\text { market }\end{array}$ & $\begin{array}{c}3 \\
190\end{array}$ & $\begin{array}{ll} & \text { BU turnover: } ~ 0.7 \\
\text { - } & 2 \text { Businesses with } \\
& \text { own sales and } \\
& \text { research }\end{array}$ & $\begin{array}{c}1 \\
220\end{array}$ \\
\hline Totals & & $\begin{array}{l}23 \\
740 \\
\end{array}$ & & $\begin{array}{c}21 \\
1270 \\
\end{array}$ \\
\hline
\end{tabular}

archival data such as articles in trade journals, which enabled us to crosscheck findings. In the second round of data collection we specifically focused on the discontinuous NPD project(s) under study. In this round we held approximately three interviews per project, representing both technical and marketing functions. By using multiple informants per project we could mitigate potential biases of any individual respondent by allowing information to be confirmed across several sources (Goldon, 1992). Multiple informants can also lead to a richer and more elaborated model, since different respondents typically focus on complementary aspects of major decisions (Dougherty, 1990). We asked respondents about the history of the project and, if the project was not introduced into the market at the moment of the interview, we also asked them to describe the project work they were doing at that moment. After this initial story, we followed up with a more in-depth discussion, focusing on specific dates, working practices, milestones, events, and outcomes. In our discussions we tried to emphasize discussing facts, which is less subject to both cognitive biases and impression management (Miller et al., 1997). The project interviews ranged from 40 minutes 
to 2 hours and were recorded and transcribed, and followed up with clarifying e-mails and telephone calls when needed. Again we complemented our interviews with internal archival data, such as presentations and press releases, and external archival data, such as general information on important competitors, customers, and applications, and media coverage. Overall the combination of two rounds of interviews and archival data collection enabled a rich understanding of the research phenomenon and provided us the opportunity for triangulation (Kumar et al., 1993).

Approaches common to qualitative case-study research (see e.g. Eisenhardt, 1989; Yin, 1994) were used to analyze our data. First we prepared a written case history per discontinuous NPD project. We used a time-oriented display in which we arranged a series of concrete events by chronological time periods. The goal of this within case analysis was to identify generalizable constructs and patterns for each case independently, in relation to the research question of how exploratory and exploitative market learning are balanced at the project level and how firms organize this balancing. After within-case analysis we turned to cross-case analysis in which the constructs and patterns that emerged from each case were compared with those from the other cases to identify consistent and inconsistent patterns and themes across cases. The comparison was initially made between pairs of projects, which was followed by adding other projects to refine findings. We then turned to an iterative process of comparing our findings with existing literature which led to the insight of how discontinuous NPD teams balance exploratory and exploitative market learning and how this balancing is managed.

\section{MARKET KNOWLEDGE AS MULTI-DIMENSIONAL CONSTRUCT}

The content of market learning is market knowledge. Knowledge in general, and market knowledge in particular, can have multiple embedded dimensions (De Luca and AtuaheneGima, 2007; Winter, 1987; Zahay et al., 2004). Additionally, market learning is a form of 'external learning' (Bierly and Chakrabarti, 1996). Organizational members have to cross the boundaries of the firm to generate market knowledge. During our analyses, we uncovered four dimensions of market knowledge: product, application, customer and segment. During discontinuous NPD the organizational market knowledge resource base was updated (exploitation) or extended (exploration) on one or more of these dimensions.

Product refers to the operational knowledge on specific 'needs and wants' that a product can satisfy in the market place. For example, if an organization has a long history of selling a specific engineering plastic, it might have developed deep knowledge on how this engineering plastic behaves in downstream manufacturing processes such as injection moulding. Additionally, it might know what properties of this engineering plastic, such as its fire resistance or electrical performance, are specifically valued by customers. If a new product is under development, the organization can do in-house tests but it is not clear how the product will behave in the actual market place, and if it really can satisfy specific "wants and needs' of customers. In these instances, it has shallow product knowledge, and needs additional 'external learning'. As one application developer put it:

....II I use an 'off the shelf' product I know much more. This material is already certified,....is used for other applications. You have a history. If I have to do a material development, I have to do some extra stuff. I have to do analyses on lab-scale, and extensively test with customers.

Application Developer Bond 
Application is about the operational knowledge on specific 'needs and wants' that a product should satisfy in certain downstream applications. If the organization has developed a knowledge base on a specific application area, such as for example automotive 'powertrain' applications, it is deeply aware of the critical application requirements in that field. If the organization does not have knowledge on a specific application area, the application knowledge base is rather shallow. Just as for product knowledge, in-house testing can generate a lot of knowledge, but real life testing often is a different story.

Customer knowledge is not focused on 'needs and wants' but on additional operational knowledge about (potential) customers which can play an important role in discontinuous NPD. This is knowledge such as contact information, company size and history, knowledge on the 'decision making unit', and knowledge on the innovation strategy.

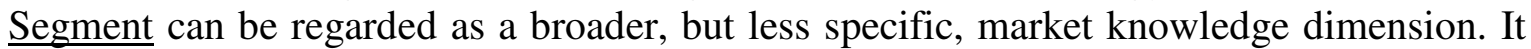
can be described as strategic knowledge. A segment can connote many elements (see e.g. Dougherty, 1990). For example, it can be centered around groups of customers, applications and/or products. Depending on how elements are emphasized or combined various market definitions are possible. Exploitative segment learning in discontinuous NPD is about updating and integrating existing segment knowledge, such as trends, growth rates, technologies or regulations. Exploratory segment learning in discontinuous NPD refers to defining a new market segment, from the perspective of the firm, and building and integrating knowledge related to that.

Both broad learning about segments and more specific learning about products, applications and customers seems necessary for successful discontinuous NPD. When there is broad learning without specific learning it is possible that the final concepts fit well against market trends, but run into all kinds of specific implementation problems. Specific learning without broad learning is expected to result in developments that are ignorant of general market trends and have limited general applicability and acceptance.

\section{MARKET LEARNING IN DISONTINUOUS NPD: THREE TYPICAL PATTERNS}

When analyzing our data, three typical patterns of market learning in discontinuous NPD projects emerged. We have structured these patterns around three generic NPD stages: ideation, development and commercialization. The patterns could be distinguished according to differences in the exploration and exploitation trade-off (Table 2).

For High Heat and Bio we find the lowest level of exploratory market learning. In these two cases the organization was developing a completely new product to replace or extend their offerings for the segment, the application and the customers that they already served. For this pattern High Heat can serve as example. In the ideation phase, or the front end of product innovation, this project showed exploitative learning on three market knowledge dimensions: segment, application and customer. Around 2003 the organization identified as trend in their segment that developments in turbo systems for automotive engines would increase future 'under the hood' temperatures (exploitation on segment). The global product team realized that their existing engineering plastic would melt at these temperatures and that they needed a new product. At their existing customers they tried to identify the people that were responsible for these new automotive developments (exploitation on customer) and tried to develop a perspective on future application requirements, such as future temperatures (exploitation on application). These future application requirements were used as parameters for developing a new material by the firm's researchers in material development, which started the development phase in 2005. 
Table 2: Three market learning patterns

\begin{tabular}{|c|c|c|c|c|c|}
\hline \multirow[b]{2}{*}{$\begin{array}{c}\text { Exploration in } \\
\text { market } \\
\text { learning } \\
\end{array}$} & \multirow[b]{2}{*}{ Cases } & \multirow[b]{2}{*}{$\begin{array}{c}\text { Market } \\
\text { knowledge } \\
\text { dimension }\end{array}$} & \multicolumn{3}{|c|}{ Generic NPD stage } \\
\hline & & & Ideation & Development & Commercialization \\
\hline$\underline{\text { Low }}$ & \multirow{4}{*}{$\begin{array}{l}\text { High Heat } \\
\text { Bio }\end{array}$} & Segment & Exploitation & Limited focus & Limited focus \\
\hline \multirow{3}{*}{$\begin{array}{l}\text { Exploration on } \\
\text { one market } \\
\text { knowledge } \\
\text { dimension } \\
\text { (existing } \\
\text { market } \\
\text { segment) }\end{array}$} & & Application & Exploitation & Exploitation & Exploitation \\
\hline & & Customer & Exploitation & Exploitation & Exploitation \\
\hline & & Product & Non existent & Exploration & Exploitation \\
\hline \multirow{4}{*}{$\begin{array}{l}\quad \text { Medium } \\
\text { Exploration on } \\
\text { two market } \\
\text { knowledge } \\
\text { dimensions } \\
\text { (existing } \\
\text { market } \\
\text { segment) }\end{array}$} & \multirow{4}{*}{$\begin{array}{l}\text { Diffuse } \\
\text { Anti-resist }\end{array}$} & Segment & Exploitation & Limited focus & Limited focus \\
\hline & & Application & Non existent & Exploration & Exploitation \\
\hline & & Customer & $\begin{array}{c}\text { Diffuse: } \\
\text { Non existent } \\
\text { Anti-resist: } \\
\text { Exploitation }\end{array}$ & $\begin{array}{c}\text { Diffuse: } \\
\text { Exploration } \\
\text { Anti-resist: } \\
\text { Exploitation }\end{array}$ & Exploitation \\
\hline & & Product & $\begin{array}{c}\text { Diffuse: } \\
\text { Exploitation } \\
\text { Anti-resist: } \\
\text { Non existent }\end{array}$ & $\begin{array}{c}\text { Diffuse: } \\
\text { Exploitation } \\
\text { Anti-resist: } \\
\text { Exploration }\end{array}$ & Exploitation \\
\hline \multirow{4}{*}{\begin{tabular}{l}
\multicolumn{1}{c}{ High } \\
Exploration on \\
three market \\
knowledge \\
dimensions \\
(new market \\
segment)
\end{tabular}} & \multirow{4}{*}{$\begin{array}{l}\text { Bond } \\
\text { Extend } \\
\text { Dye } \\
\text { Foam }\end{array}$} & Segment & Exploration & Exploitation & Limited focus \\
\hline & & Application & Non existent & Exploration & Exploitation \\
\hline & & Customer & $\begin{array}{l}\text { Bond \& Extend: } \\
\text { Non existent } \\
\text { Dye \& Foam: } \\
\text { Exploitation }\end{array}$ & $\begin{array}{l}\text { Bond \& Extend: } \\
\text { Exploration } \\
\text { Dye \& Foam: } \\
\text { Exploitation }\end{array}$ & Exploitation \\
\hline & & Product & $\begin{array}{l}\text { Bond \& Extend: } \\
\text { Exploitation } \\
\text { Dye \& Foam: } \\
\text { Non existent }\end{array}$ & $\begin{array}{l}\text { Bond \& Extend: } \\
\text { Exploitation } \\
\text { Dye \& Foam: } \\
\text { Exploration }\end{array}$ & Exploitation \\
\hline
\end{tabular}

After a period of material research aimed at understanding failure mechanisms in engineering plastics, two different material prototypes could be developed that fitted these, roughly defined, application requirements. The question was: 'How would these prototypes behave outside the laboratory?' The organization managed to find several existing customers, two tier 1 automotive suppliers and two automotive OEMs, as partners for development. Together with these partners, starting around June 2006, they extensively tested these two newly developed product prototypes, to learn about their behavior and what value they could bring in actual applications (exploration on product). They did not only try to reduce uncertainty by applying 'learning by doing', and by using 'probes' and learn from them (see e.g. Eisenhardt and Tabrizi, 1995; Lynn et al., 1996), but also aimed at updating their application and customer knowledge (exploitation on customer and application). Getting the new material from approved material into an actual new car program was the key task during commercialization. In this phase the organization continued to work with one tier 1 automotive supplier and one automotive OEM, using these organizations as launching partners. During commercialization, project members of the organization regularly had 
contacts with the downstream partners which allowed them to update their application, customer and product knowledge (exploitation). In 2008 the new product was used in a new range of vehicles. In addition to that, the organization was able to start several spin-off projects, which shows the viability of the technological and market resources which resulted from the first development path.

For Diffuse and Anti-resist we found a medium level of exploratory market learning. In the case of Diffuse, the organization targeted a well defined segment, using an existing product in a new application with a new customer. In the Anti-Resist project, the organization targeted a segment and customers that were already served by the organization, but a new product was developed for a newly uncovered application area. We will discuss this latter project in more detail to elaborate on this pattern. The ideation phase of Anti-Resist started in 2004, when sales managers of its home organization started discussions with a group of customers in the 'tires' segment on their future challenges. This segment was already served with a high performance fiber that was used for tire reinforcement. The sales managers found out that reducing the rolling resistance of tires, which can significantly improve the fuel efficiency of vehicles, was on the top of the customers' innovation lists (exploitation on segment and customer). The sales managers talked about this trend with their research department, which had the knowledge of a research program at the corporate level that was looking into the application of chemically modified fiber for rubber applications. This triggered the start up of a small research project by the firm's research department in this direction. Focusing on reducing rolling resistance, they were applying a modified fiber in rubber compounds. In 2006, the research department managed to develop a product prototype that significantly reduced rolling resistance in rubber compounds on a lab scale. Because they only had 'real life' experience with using filament yarn as reinforcement in the cap ply of tires and no knowledge on using chemically modified fiber granules (the new product) as ingredient in rubber compounds, they had to develop both market knowledge on the application and product dimension (exploration). In this phase of development, the sales managers tried to figure out what department, at a couple of innovative customers, could provide the most useful feedback and would be desirable testing partners to develop this new knowledge (exploitation on customer). A testing trajectory with market feedback loops, where knowledge on product, application and customers constantly was updated (exploitation), resulted in the first commercial quantities in 2008, spin-off projects, and the initiation of developing a second product grade to overcome some limitations of the initial new product.

The cases Bond, Extend, Dye, and Foam, make up the group that shows a high level of exploratory market learning. In the cases of Bond and Extend the home organizations targeted new applications at new customers in newly defined market segments with an existing product. In Dye and Foam the home organization targeted new applications with new products in a newly defined market segment, working with customer they already supplied with other, existing, products. For this category the Bond project can serve as example. This project started by a request of a potential customer fabricating golf shoes in 2005. This potential customer wanted to replace the metal base of golf shoes' spikes, which where overmoulded with rubber, by an engineering plastic that could resist the temperatures of the overmoulding production process. The potential customer had become aware of this specific engineering plastic because the product line advertised with it. After doing some tests it appeared that the engineering plastic behaved remarkably well during this production process. This triggered the home organization of the project to cognitively frame a new market segment for this existing engineering plastic, and dig deeper into it. With the background knowledge they had of their existing engineering plastic, such as test data of current customers, they tried to structure, list and explore possible applications in this segment. (exploration on segment; exploitation on product). They decided to focus on 
replacing metal backbones of metal/ rubber components. They further framed the segment by deciding to focus on automotive applications, where potential volumes are large and metal replacement for weight savings is high on the agenda. After some in-house tests the project members believed they could bring value in anti-vibration applications, such as strut mounts and exhaust hangers. They tried to get in contact with tier 1 manufacturers of these metal/ rubber components, which were not customers at that moment, trying to convince them to start testing programs with their engineering plastic instead of metal. They managed to convince several tier 1's to start testing their material in a wide range of anti-vibration applications, by which the project entered the development phase in 2006. This provided the project members the opportunity to refine their knowledge on this new segment (exploitation on segment) and their existing engineering plastic (exploitation on product), and to start developing and using new knowledge on these new potential customers (exploration on customer) and anti-vibration applications (exploration on application). During the development stage in which the project members collaborated with a group of prospects, they learned that some cheaper alternative materials could better serve customer needs in antivibration applications and that is was very difficult to move further in this direction. However, due to collaborative efforts with potential customers they identified new applications in the automotive metal/ rubber area (exploration on application) during 2007. It appeared that their engineering plastic was one of the few that could replace metal in some specific metal/ rubber oil seal applications. The project members updated their decisions on application focus, based on new information, which is in line with the observations of Cheng and Van de Ven (1996). They slightly changed the application scope within the metal/ rubber segment and started to update their segment knowledge, regarding trends and market size focusing on these newly identified applications (exploitation on segment). In 2008, the project members managed to get their material approved for an oil-seal project that a tier 1 was doing with an automotive OEM, marking the start of the commercialization phase. During this phase, they were in contact with the tier 1 and updated and refined their product, application, and customer knowledge (exploitation), to deliver a product that could be manufactured, delivered and priced in such a way that it fulfilled customer needs. The automotive OEM has planned to introduce the vehicle with the engineering plastic oil seal early 2010. Additionally, several spin off projects in the oil seal area are under development.

Using a process perspective on market learning in discontinuous NPD results in the observation that exploratory market learning, defined as the organizational generation and integration of new market knowledge, alone is not enough to introduce a new product that fulfills customer needs. From this perspective, periods of convergence, in which market knowledge is being refined by means of exploitative market learning, are just as important as periods of divergence. These patterns of market learning allow organizations to explore new market knowledge and at the same time refine it in such away that they can capture the benefits of this exploration. Additionally, we highlight that, at least from a marketing perspective, all discontinuous NPD is not equal. A significant number of studies relate exploration to discontinuous NPD and exploitation to continuous NPD (Atuahene-Gima et al., 2005; Dewar and Dutton, 1986; Tushman and Anderson, 1986). Other research has identified a technological and market knowledge dimension on which exploration and/or exploitation in discontinuous NPD can take place (Danneels, 2002; Zhou et al., 2005). By focusing on the market knowledge dimension, we highlight a finer-grained view. In our discontinuous NPD projects, market knowledge can be broken down into four dimensions. Each discontinuous NPD project exploits on some dimensions, while explores on others (Gatignon et al., 2002). This finer-grained perspective allows us to identify three types of discontinuous NPD, based on differences in market learning patterns. In this categorization, even projects with the highest level of exploratory market learning still rely on some level of 
exploitative market learning. This observation is in line with Nelson and Winter's (1982) claim that even the most innovative form of exploration is built on a small set of existing firm resources. This possibility to leverage existing resources also rationalizes the choice to internalize the project in the business unit, and perform it within its boundaries (O'Reilly and Tushman, 2008)

If we except the premise that managing the two inconsistent types of market learning in one project is a difficult task (Gupta et al., 2006) it is interesting to analyze what organizational arrangement allowed project members to perform this task. Our analysis on this issue discloses two different approaches. The first approach seems to fit situations where a project's market learning stays within the existing market segment and market learning shows a low to medium level of exploratory market learning. The second approach seems to fit situations with newly defined market segments resulting in high levels of exploratory market learning.

\section{MARKT LEARNING WITHIN EXISTING MARKET SEGMENTS}

In table 3 we present an overview of the nature of different arrangements in marketing organization that support discontinuous NPD market learning patterns that stay within existing market segments and have a low to medium level of exploratory market learning. We distinguish between the discontinuous NPD project's core marketing function, the NPD process in use, senior management's role in market learning, and main knowledge generation and integration mechanisms.

The marketing function is uniquely positioned as the primary link between the organization and its customers and is critically important to many of the functions and processes within most organizations (Day, 1994; Moorman and Rust, 1999). In the context of NPD, the marketing function should connect the customer to product design by bringing an 'outside in' perspective' (Day, 1994). This unique perspective is what provides the marketing function with a differentiated knowledge or skill base and puts it in the center on market learning for discontinuous NPD. In our projects there often were several organizational members performing parts of the marketing function, but in each project we are able to identify a core marketing function. This function was responsible for the larger part of the market learning activities in the project and was not always a marketing specialist, which is in line with the findings of O'Connor (1998) and Workman (1993). In Bio and Anti-resist, sales managers performed this role in all three generic NPD phases. In High heat the core marketing function was in the hands of the R\&D department, while for Diffuse a marketing manager took on this role in ideation and development, and a product manager took over in the commercialization phase. In all four projects, exploratory and exploitative market learning was separated at the operational level and a low level of market learning specialization was used. The marketing functions balanced exploratory and exploitative market learning within the discontinuous NPD project under study but were also involved in other routine marketing tasks, mostly involving exploitative market learning, such as general service delivery.

We now turn the NPD processes that were used in these developments. Formal NPD processes such as Stage-Gate processes can help a firm's product development efforts by means of introducing discipline, improving performance, enhancing efficiency and reducing new product cycle time (Cooper, 2001). It can assist market learning in discontinuous NPD by decreasing knowledge integration barriers due to differing learning responsibilities across functions and encouraging task completion and decision-making (Griffin and Hauser, 1996). However, research has highlighted that one NPD process does not fit all. NPD processes for discontinuous NPD seem to require a higher emphasis on flexibility and experimentation, because of higher levels of uncertainty, and emphasize other elements than processes for 
incremental product updates (Eisenhardt and Tabrizi, 1995; Sethi and Iqbal, 2008; Veryzer, 1998).

Table 3: Organizational arrangements

\begin{tabular}{|c|c|c|c|c|}
\hline $\begin{array}{r}\text { Low / Medium } \\
\text { exploration } \\
\text { cases } \Rightarrow \\
\text { Arrangements } \\
\Downarrow\end{array}$ & $\begin{array}{c}\text { High heat } \\
\text { (Exploration on } \\
\text { product) }\end{array}$ & $\begin{array}{c}\text { Bio } \\
\text { (Exploration on } \\
\text { product) }\end{array}$ & $\begin{array}{c}\text { Diffuse } \\
\text { (Exploration on } \\
\text { customer and } \\
\text { application) }\end{array}$ & $\begin{array}{l}\text { Anti-resist } \\
\text { (Exploration on } \\
\text { product and } \\
\text { application) }\end{array}$ \\
\hline $\begin{array}{l}\text { Core } \\
\text { marketing } \\
\text { function }\end{array}$ & $\begin{array}{l}\text { I, D, C: Application } \\
\text { developer (R\&D)*; } \\
\text { Low market } \\
\text { learning } \\
\text { specialization }\end{array}$ & $\begin{array}{l}\text { I, D, C: Sales } \\
\text { department; Low } \\
\text { market learning } \\
\text { specialization }\end{array}$ & $\begin{array}{l}\text { I\&D: Marketing } \\
\text { manager. } \\
\text { C: Product } \\
\text { manager; Both low } \\
\text { market learning } \\
\text { specialization }\end{array}$ & $\begin{array}{ll} & \text { I, D, C: Sales } \\
& \text { manager; Low } \\
& \text { market learning } \\
& \text { specialization }\end{array}$ \\
\hline NPD process & $\begin{array}{l}\text { D\&C: Standardized } \\
\text { process, loosely } \\
\text { used }\end{array}$ & $\begin{array}{ll} & \text { D\&C: Setting } \\
& \text { milestones } \\
\text { - } & \text { Asked assistance } \\
& \text { from other BU }\end{array}$ & $\begin{array}{l}\text { - I, D, C: No process } \\
\text { used }\end{array}$ & $\begin{array}{ll}\text { D\&C: } \\
\text { Standardized } \\
\text { process, loosely } \\
\text { used }\end{array}$ \\
\hline $\begin{array}{l}\text { Senior } \\
\text { management } \\
\text { and it's role in } \\
\text { market } \\
\text { learning }\end{array}$ & 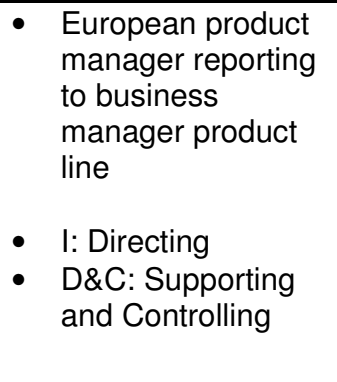 & $\begin{array}{l}\text { Business } \\
\text { manager } \\
\text { reporting to } \\
\text { executive } \\
\text { committee total } \\
\text { company } \\
\text { - I: Directing } \\
\text { - D\&C: Supporting } \\
\text { and Controlling }\end{array}$ & $\begin{array}{ll}\text { - } & \text { Executive } \\
\text { committee BU } \\
\text { - } \\
\text { I: Framing } \\
\text { (application } \\
\text { segment) } \\
\text { D: Limited } \\
\text { - } \text { C: Reviewing, } \\
\text { Supporting and } \\
\text { Controlling }\end{array}$ & $\begin{array}{ll}- & \text { Executive } \\
\text { committee BU } \\
\\
\text { - I: Framing } \\
\text { (application } \\
\text { segment) } \\
\text { D\&C: } \\
\text { Reviewing, } \\
\text { Supporting and } \\
\text { Controlling }\end{array}$ \\
\hline $\begin{array}{l}\text { Main market } \\
\text { knowledge } \\
\text { generation } \\
\text { mechanisms }\end{array}$ & $\begin{array}{ll}- & \text { I: Visiting } \\
\text { conferences \& } \\
\text { customers } \\
\text { D\&C: collaboration } \\
\text { with customer }\end{array}$ & $\begin{array}{l}\text { I: Desk research; } \\
\text { visiting customers } \\
\text { D\&C: } \\
\text { collaboration with } \\
\text { customers }\end{array}$ & $\begin{array}{ll}\text { - } & \text { I: Presenting at } \\
\text { conferences; visiting } \\
\text { potential customer } \\
\text { D\&C: collaboration } \\
\text { with potential } \\
\text { customer }\end{array}$ & $\begin{array}{ll}- & \text { I: Visiting } \\
& \text { customers } \\
- & \text { D\&C: } \\
& \text { collaboration } \\
& \text { with customers }\end{array}$ \\
\hline $\begin{array}{l}\text { Main market } \\
\text { knowledge } \\
\text { integration } \\
\text { mechanisms }\end{array}$ & $\begin{array}{l}\text { - } \quad \text { I: Executive leader } \\
\text { - } \quad \text { D\&C: Formalized } \\
\text { team meetings }\end{array}$ & $\begin{array}{ll}- & \text { I: Executive } \\
\text { leader } \\
\text { - } \quad \text { D\&C: Formalized } \\
\text { team meetings } \\
\text { - } \quad \text { Extra integration } \\
\text { function created }\end{array}$ & $\begin{array}{ll} & \text { I\&D: One person } \\
\text { performed } \\
\text { marketing and } \\
\text { technical function } \\
\text { - } \quad \text { C: Informal contacts }\end{array}$ & $\begin{array}{ll}- & \text { I: Informal } \\
\text { contacts } \\
\text { - D\&C: } \\
\text { Formalized team } \\
\text { meetings } \\
\text { - Extra integration } \\
\text { function created }\end{array}$ \\
\hline
\end{tabular}

*Legend: I = Ideation; D = Development; C = Commercialization

In two projects, no standardized NPD process was used. For Bio, the team planned and evaluated progress by developing ad-hoc project specific milestones. Because projects of this size and uncertainty (a plant had to be extended) were not common for the business unit, the team believed they did not have a standardized process that could be used in this case. They developed their milestones with the help of another business unit, which recently had commercialized a project comparable in size and uncertainty level. In project Diffuse exploratory market learning could be observed on the customer and application dimensions. Limited work was done by the organizational research organization, resulting in a relatively small in-house project, heavily relying on the product development skills of the potential customer. Because in house NPD activities were limited and unstructured no formal NPD process was used. In both High heat and Anti-resist standardized NPD processes were used. 
These same processes are used throughout the business unit for the development and commercialization phases of different NPD projects. Due to higher uncertainty levels, the standardized processes were loosely used, with several planning update cycles.

As key leaders in organizations, senior managers have a large influence on balancing explorative and exploitative learning in NPD (Atuahene-Gima et al., 2005; McGrath, 2001; Smith and Tushman, 2005). From the perspective of the NPD projects that we studied, senior management can be seen as middle and/or upper level managers in a business unit that are not involved in day-to-day project activities but are involved as resource providers. Balancing attention between exploration and exploitation makes senior management roles highly pluralistic (Floyd and Lane, 2000; Van de Ven et al., 1999). Senior managers need to perform different decision roles, impacting different NPD learning types. We can identify several specific senior management roles for market learning during discontinuous NPD. In the initiation phase of projects with a low to medium level of exploratory market learning, we can identify two types of roles: directing and framing. Directing, which we found in High heat and Bio, is a rather top-down approach in which senior management directs the allocation of resources in the pursuit of new specific market knowledge to develop a business case. When directing, senior management is actively involved in market learning on the segment dimension and delegates market learning on the product, application and customer dimensions. As a senior leader described to us:

......Five years ago, we (global product team), saw from market trends that (product) was also running into its technological limits....then it is your duty, as market leader, to develop the next generation material....That is why this development was born. Look...we recognized a trend and then we asked them (application developers) to actively visit OEMs to acquire application requirements

European product manager High heat

When framing, as in the case of Diffuse and Anti-resist, senior management aims at articulating specific market segments where it wants to be innovative, but is not operationally involved in actual market learning. In these two cases, these are existing market segments, defined by application: light management applications for Diffuse, and tires for Anti-resist. The market learning frame has to move the energies which circulate within the organizations and steer them towards developing and integrating new market knowledge. As one project member explained:

........There was not a pressure to come up with new ideas, but now we are looking for an extension of the plant.....our management was always telling that we were sold-out, but we are expanding now and we need the future to be bright also..... So now we are looking for new applications in our segments

Sales manager Anti-Resist

In the later phases of development and commercialization, three subsequent senior management roles can be identified: reviewing, supporting and controlling. Reviewing occurs in the cases where senior management used the 'framing' role in the ideation phases. Because in these cases market learning in the ideation phase was not directed by senior management, market learning patterns were emergent. Senior management was not aware of their details until the initiators needed organizational commitment and/or additional resources, sooner or later, for continuing market learning in their project. A process of reviewing occurred in which the discontinuous NPD project and its market knowledge production was evaluated 
and ratified by senior management. This reviewing role could not be identified in the two projects where 'directing' was used in the initiation phase (High heat and Bio). These projects were initiated by senior management and therefore were ratified a priori. During further development and commercialization, senior management used combinations of supporting and controlling roles in all four projects. One the one hand, they supported and coached the operational managers in interpreting and integrating market knowledge that was generated and provided input in meetings where next steps were discussed. On the other hand, they were keen on deadlines, and forced transitions in types of market learning when they thought this was necessary. As the following examples illustrate:

At the OEM, we deal with the purchaser, the technical department and their central research department.... We also have the same disciplines.....if you put the technicians together (from both sides), they probably like each other and love to talk about the application....that is also the danger in these kind of developments. It is my responsibility....to keep a clear and focused discussion. We can develop forever, but at some point you have to be driven by an end goal and generate business

At some moment we had two base recipes, and internally they wanted to do some extra iterations...... but we, as global product team, said we have to go for customer interaction now...otherwise it is impossible to reach the deadline for the new car program and we have to wait several years

European product manager High heat

As was stated in the beginning of this section, we also focused on the project's main market knowledge generation and integration mechanisms. There are many market research techniques described in the literature that are specifically suited to generate market knowledge in discontinuous NPD (Janssen and Dankbaar, 2008; Leonard-Barton, 1995; O'Connor, 1998; Urban and Von Hippel, 1988). We add to this research that different techniques appear to be used in different phases of the discontinuous NPD process and that market knowledge is generated on different dimensions. To generate market knowledge in the ideation phase, project members in the cases that showed low to medium exploratory market learning relied upon: desk research, visiting and presenting at conferences, and visiting (potential) customers. This way, they generated both a broad and a more specific market perspective and updated their segment, application and customer knowledge. This environmental scanning, in which project members in three of the four projects heavily relied upon existing customer links, opened project members' eyes to discontinuous NPD opportunities. In the phases of development and commercialization, project members focused their attention and showed market learning behavior on specific market knowledge dimensions (product, application, and customer). In these phases project members had to make trade offs between collaboration with customers, and the advantage of further internal development. As one project member described, this was not an easy task:

A major challenge is that on the one hand we are in some kind of commercialization phase where the product is put up for certification and a lot of things have to be frozen.....but on the other hand we cannot easily freeze things from the perspective of optimizing development

Project coordinator Anti-resist 
In the cases of High heat and Anti-resist, where project members knew the segment, they very consciously aimed at developing partnerships with fast implementers, and customers that they thought were willing to share test data:

if you go to (market leader), it is difficult to get a feedback, (market leader) is always.... very conservative company, very innovative, but they do not want to share information, (market leader) is number one of course, you can not ignore that, they are innovative and they are number one, so you go an interview them and give them the material. Besides that... if you look at the smaller ones, like (companies names), these are tier two companies...they give a quite good feedback. The volume is less but they give a good feedback. But these tier two are always followers, they follow the tier ones. But there is also tier three, which are much smaller and want to grow up...They are very keen to implement faster. There we are selling today, to the tier three companies...

Sales manager Anti-resist

In Bio, where the new product was replacing a relatively commoditized product, collaboration patterns were less tight. Project members relied on broad sampling of their new product prototype. In project Diffuse, a more reactive process could be observed. A potential customer, generally known for its' innovativeness, approached the organization after it held several presentations on trade conferences on a small adaptation of their current product, with an idea. During product development and commercialization this contact was intensified.

Literature has highlighted a number of market knowledge integration mechanisms, such as hierarchies of authority, direct contacts, liaison roles and teams (De Luca and AtuaheneGima, 2007; Griffin and Hauser, 1996; Olson et al., 1995). For projects that had a low to medium level of exploratory market learning, we observed various market knowledge integration mechanisms that were used in the ideation phase. In High heat and Bio integration mainly took place within the hierarchy of authority. Senior managers were responsible for integrating different streams of knowledge and developing the business case. In the ideation and development phase of Diffuse knowledge integration occurred via one person. This employee performed both the marketing and the technological function. For Anti-resist market knowledge integration in ideation occurred via informal (direct) contacts. During development and commercialization of High heat, Bio, and Anti-resist market knowledge was integrated by using formalized team meetings. During the commercialization of Diffuse, market knowledge was integrated by means of informal contacts. Additionally, we found that in Bio and Anti-resist the organization created an extra function, totally dedicated to project coordination and knowledge integration.

\section{MARKET LEARNING IN NEWLY DEFINED MARKET SEGMENTS}

Below we present our findings on organizational arrangement for market learning in discontinuous NPD which involves the definition of a new market segment and a high level of exploratory market learning (table 4).

Again we find a variety of organizational disciplines that performed the marketing function in these projects. The core marketing function for Bond was performed by an application developer from the R\&D department in all three generic NPD phases. Later in the process a sales manager was added. In project Extend a marketing manager and several sales managers were active in this function during the entire process. For Dye and Foam this function was in the hands of marketing managers. What we specifically found in these projects is that the core marketing function had a higher level of market learning specialization than the core marketing function in discontinuous NPD projects with a low to medium level of exploratory market learning. In Bond and Extend this high market learning 
specialization became evident due to the fact that these marketing functions were solely responsible for market learning in their individual projects.

Table 4: Organizational arrangements

\begin{tabular}{|c|c|c|c|c|}
\hline $\begin{array}{r}\text { High } \\
\text { exploration } \\
\text { cases } \Rightarrow \\
\underset{\Downarrow}{\text { Arrangements }}\end{array}$ & $\begin{array}{c}\text { Bond } \\
\text { (Exploration on } \\
\text { segment, application, } \\
\text { customer) }\end{array}$ & $\begin{array}{l}\text { Extend } \\
\text { (Exploration on } \\
\text { segment, } \\
\text { application, } \\
\text { customer) }\end{array}$ & $\begin{array}{c}\text { Dye } \\
\text { (Exploration on } \\
\text { segment, application, } \\
\text { product) }\end{array}$ & $\begin{array}{c}\text { Foam } \\
\text { (Exploration on } \\
\text { segment, } \\
\text { application, product) }\end{array}$ \\
\hline $\begin{array}{l}\text { Core } \\
\text { marketing } \\
\text { function }\end{array}$ & $\begin{array}{l}\text { - I, D, C: Application } \\
\text { developer (R\&D); * } \\
\text { - D\&C: sales } \\
\text { manager } \\
\text { Both high market } \\
\text { learning } \\
\text { specialization }\end{array}$ & $\begin{array}{l}\text { - I, D, C: } \\
\text { marketing and } \\
\text { sales managers; } \\
\text { All high market } \\
\text { learning } \\
\text { specialization }\end{array}$ & $\begin{array}{l}\text { - I, D, C: marketing } \\
\text { manager; High } \\
\text { market learning } \\
\text { specialization }\end{array}$ & $\begin{array}{l}-\quad \text { I, D, C: marketing } \\
\text { manager; High } \\
\text { market learning } \\
\text { specialization }\end{array}$ \\
\hline NPD process & $\begin{array}{l}\text { D\&C: Standardized } \\
\text { process, loosely } \\
\text { used }\end{array}$ & $\begin{array}{l}\text { I, D, C: Team } \\
\text { created own } \\
\text { process, with } \\
\text { specific segment } \\
\text { exploration part }\end{array}$ & $\begin{array}{ll}- & \text { I: Specific segment } \\
\text { exploration process } \\
\text { - D: Standardized } \\
\text { process, loosely } \\
\text { used } \\
\text { C: specific process } \\
\text { for transformation to } \\
\text { core organization }\end{array}$ & $\begin{array}{ll}\text { I: Specific } \\
\text { segment } \\
\text { exploration } \\
\text { process } \\
\text { - D: Standardized } \\
\text { process, loosely } \\
\text { used } \\
\text { C: specific } \\
\text { process for } \\
\text { transformation to } \\
\text { core organization }\end{array}$ \\
\hline $\begin{array}{l}\text { Senior } \\
\text { management } \\
\text { and it's role in } \\
\text { market } \\
\text { learning }\end{array}$ & $\begin{array}{l}\text { European product } \\
\text { manager reporting to } \\
\text { product line business } \\
\text { manager } \\
\text { - I: Framing (product) } \\
\text { - D\&C: Reviewing, } \\
\text { Supporting and } \\
\text { Controlling }\end{array}$ & $\begin{array}{l}\text { Steering committee } \\
\text { - I: Framing } \\
\text { (product) } \\
\text { - D\&C: Reviewing, } \\
\text { Supporting and } \\
\text { Controlling }\end{array}$ & $\begin{array}{l}\text { Growth initiative board } \\
\text { - I: Framing } \\
\text { (application } \\
\text { segment) } \\
\text { - D\&C: Reviewing, } \\
\text { Supporting and } \\
\text { Controlling }\end{array}$ & $\begin{array}{l}\text { Growth initiative } \\
\text { board } \\
\text { - I: Limited } \\
\text { involvement } \\
\text { - D\&C: Reviewing, } \\
\text { Supporting and } \\
\text { Controlling }\end{array}$ \\
\hline $\begin{array}{l}\text { Main market } \\
\text { knowledge } \\
\text { generation } \\
\text { mechanisms }\end{array}$ & $\begin{array}{l}\text { I: Desk research; } \\
\text { potential customer } \\
\text { visits; presenting at } \\
\text { conferences } \\
\text { - D\&C: Collaboration } \\
\text { with potential } \\
\text { customers }\end{array}$ & $\begin{array}{l}\text { - I: Desk research; } \\
\text { potential } \\
\text { customer visits; } \\
\text { presenting at } \\
\text { conferences } \\
\text { D\&C: Hiring } \\
\text { segment } \\
\text { specialists; } \\
\text { horizontal } \\
\text { alliance; } \\
\text { collaboration with } \\
\text { potential } \\
\text { customers }\end{array}$ & $\begin{array}{l}\text { - I: Desk research; } \\
\text { visiting conferences } \\
\text { and customers } \\
\text { - } \quad \text { D\&C: collaboration } \\
\text { with customer }\end{array}$ & $\begin{array}{l}\text { - I: Desk research; } \\
\text { visiting customers } \\
\text { - D\&C: } \\
\text { collaboration with } \\
\text { customers }\end{array}$ \\
\hline $\begin{array}{l}\text { Main market } \\
\text { knowledge } \\
\text { integration } \\
\text { mechanisms }\end{array}$ & $\begin{array}{ll}- & \text { I: One person } \\
\text { performed } \\
\text { marketing and } \\
\text { technical function } \\
\text { - D\&C: Formalized } \\
\text { team meetings } \\
\end{array}$ & $\begin{array}{l}- \text { I, D, C: } \\
\text { Formalized team } \\
\text { meetings }\end{array}$ & $\begin{array}{ll} & \text { I: Informal contacts } \\
\text { with core } \\
\text { organization } \\
\text { - D\&C: Formalized } \\
\text { team meetings }\end{array}$ & $\begin{array}{l}\text { - I: Informal } \\
\text { contacts with core } \\
\text { organization } \\
\text { - } \quad \text { D\&C: Formalized } \\
\text { team meetings }\end{array}$ \\
\hline
\end{tabular}

*Legend: I = Ideation; $\mathrm{D}=$ Development; $\mathrm{C}=$ Commercialization 
In these situation, integration of knowledge did not only occur through senior management, as suggested by Tushman and O'Reilly (1996), but also through operational ties. The core marketing functions, for example, directly worked together with their firm's manufacturing facilities that were responsible for routine manufacturing tasks. In the cases of Dye and Foam, market learning specialization was based on the type of learning. The marketing managers in these cases, who acted as project owners, did several other discontinuous NPD projects but heavily focused on the exploratory market learning part. For exploitative market learning they worked together with less specialized marketing functions that were also responsible for routine marketing tasks outside the scope of NPD. As Dye's marketing manager explained:

We have this big commercial organisation with the sales and the application developers. And usually my main point of entry I would say is the application developer, because they are usually the ones that work on product development. It is easy for them to bring me to a customer and say this is something new we are working on.......The thing is.....that I have a 12 years history in the company so I know these guys, I know who is working in certain areas, so I call them....

Marketing manager Dye

On NPD process we observed that in projects Dye and Foam two sub-phases were added to the generic NPD process. One that was used in the ideation phase and one that was used during commercialization. For ideation, a specific process guided the exploration of the newly defined market segments. In the commercialization phase several process steps were used in transferring the project from the marketing functions, which were specialized in exploratory market learning, to the general sales and product management organization that became involved in the spin off projects, which were in need of more exploitative market learning. In the case of Extend, there was a multifunctional team that was released from all other tasks and worked full time on the project. Because this level of exploration was very exceptional for the organization, the team decided that it needed an NPD process that suited this task which was not available in the mother organization. As the Extend R\&D manager observed:

You have to structure all the work in the right manner. For a small team it is no excuse not to do it. Very seldom you have the opportunity to start something from zero....This gives you a lot of challenges, but it gives you also the opportunity to set up internal processes in the right manner...

R\&D manager Extend

After first product commercialization, the Extend team was also in charge of the spin-off projects that were generated and further building the business. Therefore, it was not necessary for the team, and the organization as a whole, to think about transferring the results from the initial project to other parts of the organization. In the Bond case project members used the general process for development and commercialization. However, they also realized that they were actually in need of additional structuring mechanisms in the initiation phase to explore the newly defined market segment:

........(The normal NPD process) has a whole other focus...that is focused on existing things...So you already sell application $A$ and $B$ and you do a small modification in application A for a new car model. So it's me-too...our process is much more focused on that 
than on new business development. We were looking at a whole new application segment, and maybe we had to develop a specific process for that.....

Regarding senior management, we could not observe a directing, top-down, role from senior management in market learning for projects with a high level of exploratory market learning. Instead senior managers framed focus areas based on an existing product (Bond, Extend), or a new application segment (Dye) which they identified and thought could be interesting for the organization. Project foam is an exception. Here the initial idea originated from a sales manager visiting existing customers, related to another matter. By using her internal network, the sales manager transferred the idea to a marketing manager who focused on projects that require exploratory market learning. This manager defined the new segment, explored it and developed the business case. Senior management only got involved when this marketing manager, in need of more resources, presented the business case to them, marking the start of development. For development and commercialization we observed the same roles as were presented for the cases that showed low to medium exploratory market learning. Senior management reviewed the business cases and kept involved, balancing support and control.

Although different types of learning could be observed, the same market knowledge generation mechanisms were used in the initiation phases of these projects as were used for NPD projects with a low to medium level of exploratory market learning: desk research, (potential) customer visits, and conference visits and presentations. During development, market knowledge was generated by means of collaboration with one or more (potential) customers. For this type of projects we also observed additional market knowledge generation mechanisms that were applied in the development and commercialization phases. The Extend project team tried to accelerate their learning on segment by hiring a project manager and a new business development manager that had deep knowledge on the newly defined segment and were specialists on the segment that they wanted to target. In the US, the Extend team, which operated worldwide, also developed a horizontal alliance with a competitor that was an established player in the newly defined segment. Extend developed prototypes, which were marketed by the competitor, which had access to, and knowledge about, a lot of potential customers. Because the team and the competitor had close contacts and shared knowledge, the team could accelerate segment and application learning during development and commercialization.

Except for the integration by executive leaders and the extra integration function, the integration of market knowledge in the high exploratory market learning projects evolved in similar ways as was presented for the low to medium exploratory market learning projects.

\section{DISCUSSION}

We started by arguing that most research on market learning in NPD distinguishes between exploitative market learning, which is attributed to continuous NPD, and exploratory market learning which fits discontinuous NPD. We directed our attention to the second type of NPD projects. Our analyses resulted in breaking down the overarching NPD market knowledge bundle into four underlying market knowledge dimensions (segment, product, application, and customer). Based on this breakdown, we were able to identify three basic market learning patterns in discontinuous NPD projects. We could distinguish these patterns based on the trade-off between exploratory and exploitative market learning in the projects. All three patterns consisted of both exploratory and exploitative market learning periods. Exploratory market learning on a given dimension was balanced with exploitative marketing learning on that same dimension over time. In addition, exploratory market learning on one or 
more market knowledge dimensions was always balanced by exploitative market learning on one or more other market knowledge dimensions in the same time period.

We also gained insight into the organizational arrangements that allowed the project team members to combine both types of market learning. This resulted in two organizational configurations, one fitting discontinuous NPD projects that stayed within defined market segments and showed a low to medium level of exploratory market learning, and one which seems more appropriate for discontinuous NPD projects in newly defined market segments, resulting in a high level of exploratory market learning (Table 5). For the first type of projects, the core marketing function showed low market learning specialization. If NPD processes were used, they were of standardized nature. Senior management directed or framed market learning in the ideation phase. During development and commercialization, senior management was still involved and reviewed, supported and controlled market learning. Project members used desk research, conferences and (potential) customer visits to generate market knowledge in the ideation phase, and collaborated with (potential) customers to generate this knowledge in later phases. Integration of market knowledge with other types of knowledge relevant for NPD took place by using a diverse set of mechanisms in the ideation phase, and by formalized team meetings in three of the four cases during development and commercialization. In addition to these team meetings, we found that in two cases an extra knowledge integration function was created. In analyzing arrangements used in the second type of projects, we found some differences. Instead of low market learning specialization, the core marketing function showed high market learning specialization. Instead of directing, senior management framed market learning during initiation, or showed limited involvement. In addition to the market knowledge generation mechanisms that could be observed in the first type of projects, we also found two extra mechanisms in the second type of projects: hiring segment specialists, and partnering with a competitor (horizontal alliance). Both these mechanisms were used to gain a wide range of segment contacts and to accelerate market knowledge generation and interpretation.

Table 5: Organizational arrangement for two types of projects

\begin{tabular}{|c|c|c|}
\hline $\begin{array}{r}\text { Level of exploratory } \\
\text { market learning in } \\
\text { discontinuous NPD } \Rightarrow \\
\text { Arrangements } \Downarrow\end{array}$ & $\begin{array}{l}\text { Low to Medium } \\
\text { (Within defined market segment) }\end{array}$ & $\begin{array}{c}\text { High } \\
\text { (Newly defined market segment) }\end{array}$ \\
\hline Core marketing function & - Low market learning specialization & - High market learning specialization \\
\hline NPD process & - D\&C: General NPD process & $\begin{array}{l}\text { - I, D\&C*: NPD process adapted for } \\
\text { segment exploration and project } \\
\text { transfer }\end{array}$ \\
\hline $\begin{array}{l}\text { Role of senior } \\
\text { management }\end{array}$ & $\begin{array}{ll} & \text { I: Directing / Framing } \\
\text { - } & \text { D\&C: (Reviewing), Supporting and } \\
& \text { Controlling }\end{array}$ & $\begin{array}{l}\text { - I: Framing / Limited involvement } \\
\text { - D\&C: Reviewing, Supporting and } \\
\text { Controlling }\end{array}$ \\
\hline $\begin{array}{l}\text { Main market knowledge } \\
\text { generation mechanisms }\end{array}$ & $\begin{array}{l}\text { I: Desk research, conferences, } \\
\text { visiting (potential) customers } \\
\text { D\&C: collaboration with (potential) } \\
\text { customers }\end{array}$ & $\begin{array}{l}\text { I: Desk research, conferences, } \\
\text { visiting (potential) customers } \\
\text { D\&C: collaboration with (potential) } \\
\text { customers; } \\
\text { D\&C: Hiring segment specialists; } \\
\text { developing horizontal alliances }\end{array}$ \\
\hline $\begin{array}{l}\text { Main Market knowledge } \\
\text { integration mechanisms }\end{array}$ & $\begin{array}{l}\text { - I: Various } \\
\text { - D\&C: Formalized team meetings } \\
\text { - } \text { D\&C: Extra integration function }\end{array}$ & $\begin{array}{l}\text { - I: Various } \\
\text { - } \quad \text { D\&C: Formalized team meetings }\end{array}$ \\
\hline
\end{tabular}

*Legend: I = Ideation; $\mathrm{D}$ = Development; $\mathrm{C}$ = Commercialization 
In the second type of projects we did not observe an extra knowledge integration function. Maybe because of the high learning specialization of some project members, an extra knowledge integration function would make learning processes in the second type of projects too inefficient.

With our research we primarily contribute to the work that is done on market learning in NPD (Atuahene-Gima et al., 2005; Morgan and Berthon, 2008; O'Connor, 1998; Tsai et al., 2008). This stream of literature mainly takes a static, firm-level perspective and attributes exploratory market learning to discontinuous NPD and exploitative market learning to continuous NPD. We take a dynamic project-level perspective and show that for eight discontinuous NPD projects which were introduced into the market, solely relying on exploratory market learning was not enough. Project members use both exploratory and exploitative market learning to come up with innovative ideas and/or develop new products that are accepted by the market. To some extent our findings are in line with the work of Kyriakopoulos and Moorman (2004). These authors found that combining marketing exploration and exploitation strategies in single NPD projects improved new product performance, provided that the firm had a high market orientation. Our in-depth analyses allowed for an extension of this view by the identification of organizational configurations that seem to relate to the trade-off between exploration and exploitation in discontinuous NPD projects. Thus, we find evidence that the degree to which the discontinuous NPD project relates to the firm's existing market knowledge resource base should impact its' organization, instead of the newness of NPD per se. Additionally we identify two market knowledge generation methods that are not often mentioned in the literature: hiring segment specialists and developing horizontal alliances. These seem to be specifically relevant in accelerating learning in the context of discontinuous NPD projects with a high level of exploratory market learning. Our work also impacts research on 'marketing organization'. In analyzing the organization of the marketing function, this stream of research often presents antecedents in terms of discrete, contrasting categories. Workman, Homburg, and Gruner (1998), for example, talk about differentiation (exploration) or low cost (exploitation) marketing strategies, while Ruekert Walker and Roering (1985) distinguish between nonroutine (exploration) and routine (exploitation) marketing tasks. Instead of 'either/or' we emphasize paradoxical thinking and highlight that the characteristics of the trade-off between exploration and exploitation in single tasks seem to matter as well.

In a more general vein, our work relates to the branch in organization theory that is looking into complex organizational designs that provide for short-term efficiency (exploitation) and long-term innovation (exploration). To achieve this so called 'ambidexterity' (Tushman and O'Reilly, 1996), most of the solutions involving organizational structure relate to two basic underlying concepts: spatial separation and parallel structures (Raisch and Birkinshaw, 2008). On the business unit level, the spatial separation approach addresses the trade off by creating separate units that pursue either exploration or exploitation. The question here is, to what extent these units should be integrated to achieve overarching business unit goals. When using parallel structures, a business unit's formal structure is used for routine tasks that require exploitation, while a secondary structure (such as a project teams) balance the primary structure's shortcomings and support non-route tasks, requiring exploration. Rather than developing structural solutions, Gibson and Birkenshaw (2004) take another approach. These authors advocate contextual ambidexterity in which leaders create a supportive business unit context, which refers to the systems, processes and beliefs that shape individual level behaviors. Such a context should be designed to enable and encourage individuals to judge for themselves how to best divide their time between conflicting demands for exploration and exploitation. From the perspective of the discontinuous NPD marketing task environment, we could identify all three approaches to 
balancing exploration and exploitation. Within projects we observed contextual ambidexterity. To some extend project members were free to structure their work and pursue explorative and exploitative market learning over time. From a business unit perspective, we could observe that the organization of projects with a high level of exploratory market learning comes close to the spatial separation approach. The core marketing functions in these projects showed high learning specialization and used a task specific NPD process. They were able to focus the majority of their attention on exploration and/or one project, and developed operational links with other marketing functions for exploitation. In contrast, the organization of projects with a low to medium level of exploratory market learning showed organizational characteristics that come closer to the parallel structure approach. In three of the four cases formalized teams structures allowed the core marketing functions to be involved in exploratory market learning. At the same time they were also responsible for the projects' exploitative market learning and exploitative learning resulting from routine marketing tasks outside the project. Hence, the core marketing functions in these projects showed low market learning specialization. In two of these latter projects we also observed that the team's exploratory market learning was supported by an extra knowledge integration function. Our longitudinal approach also allowed us to highlight other differences in organizational arrangements between discontinuous NPD projects with different levels of exploratory market learning. Differences that, we think, would be much harder to highlight with a cross-sectional approach. The role of senior management, for example, is rather comparable across different projects in the later phases of the discontinuous NPD process, while it is much more directing in the ideation phases of projects with a low to medium level of exploratory market learning than in projects with a high level of exploratory market learning. On the contrary, the differences in market knowledge generation and integration mechanisms are far more evident in the development and commercialization phases than in the ideation phase. Overall, we find evidence that the level of exploration in market learning patterns can be seen as an important contingency variable for the organization of market learning in discontinuous NPD.

Finally, our work can be linked to the literature on strategic management in general, and the knowledge based view of the firm (Grant, 1996) in particular. Our analyses allowed us to develop a fine-grained view on a firm's market knowledge resource base and to pinpoint specific market knowledge resources that are relevant in product development. From a marketing perspective, two dominant strategic logics could be observed. Discontinuous NPD projects that stay close to the existing organizational market knowledge base were used to leverage existing market knowledge resources to remain a future leader in a market segment. For discontinuous NPD that moves further away from the existing market knowledge base, discontinuous NPD project were used to develop new market knowledge resources and develop a position in new market segments. We showed that the emphasis in this reciprocal resource - discontinuous NPD relationship is put into practice by the specific organizational arrangements applied.

\section{MANAGERIAL IMPLICATIONS}

The typology of market learning patterns in discontinuous NPD developed in our research can be used in NPD portfolio analyses. Using this typology, managers, specifically those that are active in the chemical industry, can map their current discontinuous NPD projects and identify new options. The framework calls specific attention to a project's underlying market knowledge resources. Both those that are implicitly available in the firm and 'only' need to be updated, and those that cannot be found in the firm and have to be acquired. Insight into this matter can assist firms in balancing scarce resources and developing timelines and action plans for specific discontinuous NPD projects. By repeating this analysis over time, the 
organization will gain insight into how the interplay between market knowledge resources and discontinuous NPD projects evolves. This knowledge can be used in strategy making.

Our work also sheds light on organizing market learning for different types of discontinuous NPD, or what opportunities to pursue if marketing capabilities are limited. Although capabilities to facilitate different levels of exploration can be limited, they can also be developed. Our research highlights specific organizational elements, such as marketing functions and NPD processes, which can be important candidates for targeted development.

Understanding different market learning patterns in discontinuous NPD can contribute to developing decision-making and evaluation processes tailored to the specific nature of a discontinuous NPD project. Most likely, discontinuous NPD projects that strongly deviate from the current organizational market knowledge resource base need to be secured from strict market knowledge based selection criteria. If this is not the case, it is most likely that they never will be pursued because for these projects it takes longer to develop a clearly defined and measurable market. Our research provides some guidance for developing measures for these types of discontinuous NPD projects. Decision-making guidelines should be relatively strategic and visionary. Suitable questions are, for example, 'Do we want to be in this market segment?' Do we have some market knowledge that we can leverage? What are important applications in this segment?' The same holds for new product success measurement. In instances with high levels of market knowledge exploration, it might be more appropriate to look into how a project extended the firm's market knowledge base and laid the foundation for further developments, than evaluate its product-specific objectives, such as sales figure or market share, in isolation.

\section{LIMITATIONS AND FURTHER RESEARCH}

Our findings are based on eight discontinuous NPD project in business units of multinationals that are active in the chemical industry. Obviously we cannot claim that our findings are generalizable to product innovation in all manufacturing firms, or can be extended to consumer products or services. Discontinuous NPD in the business units we studied could have idiosyncratic characteristics that impact their market learning patterns. However, we think that breaking down the construct of market knowledge, market learning, and organizational arrangements, into smaller, more analyzable components has strong conceptual appeal. Further research could extend our approach to other contexts. In our research, we solely focused on market knowledge resources. Additional research may include other important NPD knowledge resources such as manufacturing and technological knowledge. Additionally, further research may adopt a more quantitative approach and measure the impact of organizational configurations on learning patterns, and the impact of learning patterns on discontinuous NPD success. Our analyses only focus on differences in learning patterns and their organization of discontinuous NPD projects where the output could be introduced into the market. We did not include ultimate measures of NPD success, nor do we have data on projects that are cancelled during development. Further research may look into these shortcomings and paint a more complete picture of market learning in discontinuous NPD.

\section{REFERENCES}

Adams, M.E., Day, G.S., and Dougherty, D. (1998). Enhancing new product development performance: An organizational learning perspective. Journal of Product Innovation Management, 15(5), 403-422.

Atuahene-Gima, K. (1995). An exploratory analysis of the impact of market orientation on new product performance. A contingency approach. Journal of Product Innovation Management, 12(4), 275-345. 
Atuahene-Gima, K., Slater, S.F., and Olson, E.M. (2005). The Contingent Value of Responsive and Proactive Market Orientations for New Product Program Performance. Journal of Product Innovation Management, 22(6), 464-482.

Bell, S.J., Whitwell, G.J., and Lukas, B.A. (2002). Schools of thought in organizational learning. Journal of the Academy of Marketing Science, 30(1), 70-86.

Bennet, R.C., and Cooper, R.G. (1981). The misuse of marketing: An american tragedy. Business Horizons, 24(November-December), 51-61.

Bierly, P., and Chakrabarti, A. (1996). Generic knowledge strategies in the U.S. pharmaceutical industry. Strategic Management Journal, 17(Winter Special Issue), 123-135.

Cheng, Y.T., and Van de Ven, A.H. (1996). Learning the Innovation Journey: Order Out of Chaos? Organization Science, 7(6), 593-614.

Christensen, C.M., and Bower, J.L. (1996). Customer power, strategic investment, and the failure of leading firms. Strategic Management Journal, 17, 197-218.

Cooper, R.G. (2001). Winning at new products: Accelerating the process from idea to launch Perseus Publishing, Cambridge MA.

Danneels, E. (2002). The dynamics of product innovation and firm competences. Strategic Management Journal, 23, 1095-1121.

Day, G.S. (1994). The Capabilities of Market Driven Organizations. Journal of Marketing, 58(October), 37-52.

De Luca, L.M., and Atuahene-Gima, K. (2007). Market Knowledge Dimensions and CrossFunctional Collaboration: Examining the Different Routes to Product Innovation Performance. Journal of Marketing, 71(1), 95-112.

Dewar, R.D., and Dutton, J.E. (1986). The Adoption of Radical and Incremental Innovations: An Empirical Analysis. Management Science, 32(11), 1422-1433.

Dougherty, D. (1990). Understanding new markets for new products. Strategic Management Journal, 11(Summer), 59-78.

Dougherty, D., and Hardy, C. (1996). Sustained product innovation in large, mature organizations: Overcoming innovation-to-organization problems. Academy of Management Journal, 39, 1120-1153.

Duncan, R. (1976). The ambidextrous organization: Designing dual structures for innovation, in: The Management of Organizational Design, R. Kilman and L. Pondy (eds.), North Holland, New York, NY, 167-188.

Eisenhardt, K.M. (1989). Building theories from case study research. Academy of Management Review, 14(4), 532-550.

Eisenhardt, K.M., and Tabrizi, B.N. (1995). Accelerating adaptive processes: product innovation in the global computer industry. Administrative Science Quarterly, 40(1), 84-110.

Floyd, S.W., and Lane, P.W. (2000). Strategizing throughout the organization: Managing role conflict in strategic renewal. Academy of Management Review, 25(1), 154-177.

Frosch, R. (1996). The customer for R\&D is always wrong! Research-Technology Management 39(6), 22-27.

Gatignon, H., Tushman, M.L., Smith, W., and Anderson, P. (2002). A structural approach to assessing innovation: Construct Development of Innovation Locus, Type, and Characteristics. Management Science, 48(9), 1103-1122.

Gibson, C.B., and Birkinshaw, J. (2004). The antecedents, consequences, and mediating role of organizational ambidexterity. Academy of Management Journal, 47(2), 209-226.

Goldon, B. (1992). The past is the past - or is it? The use of retrospective accounts as indicators of past strategy. Academy of Management Journal, 35(4), 848-860. 
Grant, R.M. (1996). Towards a knowledge-based theory of the firm. Strategic Management Journal, 17(Winter special issue), 109-122.

Griffin, A., and Hauser, J.R. (1996). Integrating R\&D and Marketing: A review and anaysis of the literature. Journal of Product Innovation Management, 13(3), 191-215.

Gupta, A.K., Smith, K.G., and Shalley, C.E. (2006). The interplay between exploration and exploitation. Academy of Management Journal, 49(4), 693-706.

Janssen, K.L., and Dankbaar, B. (2008). Proactive involvement of consumers in innovation: Selecting the appropriate techniques. International Journal of Innovation Management, 12(3), 511-541.

Jaworski, B.J., Kohli, A.K., and Sahay, A. (2000). Market-Driven versus Driving Markets. Journal of the Academy of Marketing Science, 28(1), 45-54.

Johne, A. (1994). Listening to the voice of the market. International Marketing Review, 11(1), 47-59.

King, A.W., and Zeithaml, C.P. (2003). Measuring organizational knowledge, a conceptual and methodological framework. Strategic Management Journal, 23(8), 663-772.

Kirca, A.H., Jayachandran, S., and Bearden, W.O. (2005). Market orientation: A metaanalytic review and assessment of its antecedents and impact on performance. Journal of Marketing, 69(2), 24-41.

Kohli, A.K., and Jaworski, B.J. (1990). Market orientation: The construct, research propositions, and managerial implications. Journal of Marketing, 54(2), 1-18.

Kumar, N., Stern, L.W., and Anderson, J. (1993). Conducting interorganizational research using key informants. Academy of Management Journal, 36(6), 1633-1651.

Kyriakopoulos, K., and Moorman, C. (2004). Tradeoffs in marketing exploitation and exploration strategies: The overlooked role of market orientation. International Journal of Research in Marketing, 21(3), 219-240.

Leonard-Barton, D. (1995). Wellsprings of Knowledge Harvard Business School Press, Boston, MA.

Li, T., and Calantone, R. (1998). The impact of market knowledge competence on new product advantage: Conceptualizations and empirical examination. Journal of marketing, 62(October), 13-29.

Lynn, G.S., Morone, J.G., and Paulson, A.S. (1996). Marketing and discontinuous innovation: The probe and learn process. California Management Review, 38(3), 837.

March, J.G. (1991). Exploration and exploitation in organizational learning. Organization Science, 2, 71-87.

McGrath, R.G. (2001). Exploratory learning, innovative capacity and managerial oversight. Academy of Management Journal, 44(1), 118-131.

Miller, C.C., Cardinal, L.B., and Glick, W.H. (1997). Retrospective reports in organizational research: a reexamination of recent evidence. Academy of Management Journal, 40(1), 189-204.

Moorman, C. (1995). Organizational market information processes: Cultural antecedents and new product outcomes. Journal of Marketing Research, 32(August), 318-335.

Moorman, C., and Rust, R.T. (1999). The role of marketing. Journal of Marketing, 63(special issue), $180-197$.

Morgan, R.E., and Berthon, P. (2008). Market Orientation, Generative Learning, Innovation Strategy and Business Performance Inter-Relationships in Bioscience Firms. Journal of Management Studies, 45(8), 1329-1353.

Narver, J.C., and Slater, S.F. (1990). The effect of a Market Orientation on Business Profitability. Journal of Marketing, 54(October), 20-35. 
Narver, J.C., Slater, S.F., and MacLachlan, D.L. (2004). Responsive and proactive market orientation and new product success. Journal of Product Innovation Management, 21(5), 334-347.

Nelson, R.R., and Winter, S.G. (1982). An evolutionary theory of economic change Harvard University Press, Boston MA.

O'Connor, G. (1998). Market learning and radical innovation: A cross case comparison of eight radical innovation projects. Journal of Product Innovation Management, 15(2), 151-161.

O'Reilly, C., and Tushman, M.L. (2008). Ambidexterity as a Dynamic Capability: Resolving the Innovator's Dilemma. Research in Organizational Behavior 28, 185-206.

Olson, E.M., Walker, O.C., and Ruekert, R.W. (1995). Organizing for effective new product development: The moderating role of product innovativeness Journal of Marketing, 59(1), 48-62.

Raisch, S., and Birkinshaw, J. (2008). Organizational Ambidexterity: Antecedents, Outcomes, and Moderators. Journal of Management, 34(3), 375-409.

Sethi, R., and Iqbal, Z. (2008). Stage-Gate Controls, Learning Failure, and Adverse Effect on Novel New Products. Journal of Marketing, 72(Januari), 118-134.

Slater, S.F., and Narver, J.C. (1998). Customer-led and Market-Oriented: Let's not confuse the two. Strategic Management Journal, 19, 1001-1006.

Smith, W.K., and Tushman, M.L. (2005). Managing Strategic Contradictions: A Top Management Model for Managing Innovation Streams. Organization Science, 16(5), 522-536.

Song, M.X., and Montoya-Weiss, M.M. (1998). Critical Development Activities for Really New versus Incremental Products. Journal of Product Innovation Management, 15(2), 124-135.

Sorescu, A.B., Chandy, R.K., and Prabhu, J.C. (2003). Sources and financial consequences of radical Innovation: Insights from pharmaceuticals. Journal of marketing, 67(October).

Thompson, J.D. (1967). Organizations in action McGraw-Hill, New York.

Tsai, K.-H., Chou, C., and Kuo, J.-H. (2008). The curvilinear relationships between responsive and proactive market orientations and new product performance: A contingent link. Industrial Marketing Management, 37(8), 884-894.

Tushman, M.L., and Anderson, L. (1986). Technological discontinuities and organizational environments Administrative Science Quarterly, 31, 439-465.

Tushman, M.L., and O'Reilly, C. (1996). Ambidextrous organizations: Managing evolutionary and revolutionary change. California Management Review, 38(4), 8-31.

Urban, G., and Von Hippel, E. (1988). Lead user analyses for the development of new industrial products. Management Science, 5, 569-582.

Van de Ven, A.H., Polley, D.E., Raghu, G., and Venkataraman, S. (1999). The innovation journey Oxford University Press, New York.

Veryzer, R.W. (1998). Discontinuous innovation and the new product development process. Journal of Product Innovation Management, 15, 304-321.

Winter, S.G. (1987). Knowledge and competence as strategic assets, in: The competitive challenge. Strategies for Industrial Innovation and Renewal, D.J. Teece (ed.), Ballinger, Cambridge.

Workman, J.P. (1993). Marketing's limited role in new product development in one computer systems firm. Journal of Marketing Research, 30(4), 405-421

Workman, J.P., Homburg, C., and Gruner, k. (1998). Marketing organization: An integrative framework of dimensions and determinants. Journal of Marketing, 62(3), 21-41.

Yin, R.K. (1994). Case study research: Design and methods SAGE Publications, Thousand Oaks, CA. 
Zahay, D., Griffin, A., and Fredericks, E. (2004). Sources, uses, and forms of data in the new product development process. Industrial Marketing Management, 33(7), 657-666.

Zhou, K.Z., Yim, C.K., and Tse, D.K. (2005). The Effects of Strategic Orientations on Technology- and Market-Based Breakthrough Innovations. Journal of Marketing, 69(2), 42-60. 